\title{
南九州畑作地域における畑地高度利用技術の経営的評価
}

ーダイコンーサツマイモ畦連続使用栽培体系を対象として一

\author{
房安功太郎 1)*・新美洋 2)・千田 雅之 ${ }^{1)}$
}

\section{The Economic Effects of Introducing a Radish and Sweet Potato Double Cropping System on an Upland Farm in Southern Kyusyu}

\author{
Kotaro Fusayasu' ${ }^{1 *}$, Hiroshi $\mathrm{Niimi}^{2)} \&$ Masayuki Senda ${ }^{1)}$
}

\begin{abstract}
A radish and sweet potato double cropping system is an effective method for reducing growth injury caused by continuous cropping. In addition, this method enables farmers to reduce working hours and production expenses. By using the ridge continuously for radishes in the winter and sweet potato in the summer, farmers can reduce plowing and ridging work before planting sweet potatoes. This paper evaluates economic effects on an upland
\end{abstract} キーワード：技術評価，南九州畑作，畑地高度利用，線形計画モデル，環境

\section{1. はじめに}

\section{(1) 研究の背景}

南九州畑作地域 1 では, 往時は澱粉原料用甘藷, 麦，ナタネ，そば等の作付けが盛んであり，これら の作物を組久合わせた輪作が行われていた。しかし ながら，高度成長期以降の農産物輸入自由化の下で それら作物の競争力が低下し, 代わって焼酎原料用 甘藷，根菜類を中心とする露地野菜，飼料用作物等 の作付けが拡大した。 このような商品生産農業への 転換により，収益性の高い作物を優先的に作付け寸 るようになり，またマルチ被覆栽培の普及による作 期延長等を背景にその前後作を排除する傾向が強ま った. 結果, 甘藷や野菜の単作化・連作化が進行し, 伝統的な輪作体系は失われた。

このような変化により，農家一戸あたり所得は増 farm obtained by introducing this cultivation method using a business analysis of a family-run farm in Southern Kyusyu. The results are as follows: (1) Working hours are reduced by 3.3 hours per 10 a compared with the conventional cultivation method. (2) The costs of radish and sweet potato production are reduced by 19,500 yen per 10 a compared with the conventional cultivation method. (3) Farming income increases by $15 \%$.

加したものの，他の畑作地域と比較すると未だ低い 水準にある.ささら，輸入野菜の増加等により近年 野菜価格が下落傾向にあり, 農業所得の向上が経営 面での課題となっている（金岡，2010）。一方，環 境面では，作付けの単作化により肥料の多投入，殺 虫剂の多用（連作に上る病虫害の発生による）が一 般化し，環境への影響が問題視されている。そのた め, 環境に配慮した作付け体系の再構築が課題とな っている（持田，1995）。

\section{（2）課題解決に向けた新技術}

そのような中, 近年の栽培技術の発達により甘藷 と野菜による新たな輪作体系が構築可能となり, 農 家の所得向上と環境負荷低減を実現できる可能性が 生ま水ている, その一つが, 九州沖縄農業研究七ン ターの開発したダイコンーサッマイモ畦連続使用栽

\footnotetext{
1) 農研機構中央農業総合研究センター; National Agricultural Research Center, NARO

2) 農研機構九州沖縄農業研究センター; Kyusyu Okinawa Agricultural Research Center, NARO

*E-mail: fusayasu@affrc.go.jp

(C)地域農林経済学会
} 
表 1. 期待される新技術の導入効果

\begin{tabular}{|c|c|c|}
\hline 要素技術名 & 経営面 & 環境面 \\
\hline \multirow{2}{*}{ 畦の連続使用 } & 作業省略による省力化 & \multirow{2}{*}{$\begin{array}{l}\text { 線虫発生防止, } \\
\text { 殺虫剂の使用減 }\end{array}$} \\
\hline & 資材費の削減 & \\
\hline \multirow{2}{*}{$\begin{array}{l}\text { 施肥の共通化・ } \\
\text { 合理化 }\end{array}$} & 施肥作業の省力化 & \multirow{2}{*}{$\begin{array}{l}\text { 肥料の多投入に } \\
\text { よる土㙥蓄積・ } \\
\text { 溶脱防止 }\end{array}$} \\
\hline & $\begin{array}{l}\text { 一作物あたり肥料費の } \\
\text { 削減 }\end{array}$ & \\
\hline \multirow{2}{*}{ 畦間えん麦間作 } & 畴間除草作業の省力化 & \multirow{2}{*}{ 除草剂の使用減 } \\
\hline & 除草剂費の削減 & \\
\hline
\end{tabular}

培体系（以下，新技術とする）である.これは，南 九州の主要作物である春大根と甘藷の二毛作に，畦 間でのえん麦間作を組み合わせた栽培体系である. 春大根と甘諸の交互作ではなく二毛作である点が特 徵であり，前後作を通した肥培管理の共通化・合理 化により一作物あたりの作業時間, 資材費の削減を 図っている，具体的には，1）大根と甘藷に共通使用 できる幅広で高さのある畦を開発し，前作（大根） で使用した畦を連続して後作（甘藷）に使用するこ とによる甘諸移植前の耕耘・畦立て・マルチ被覆作 業の省略と資材費の削減，2）緩効性の肥料（牛糞堆 肥と窒素肥料の併用）を大根播種前に一括施用する ことによる甘藷移植前の施肥作業の省略と前後作を 通した肥料養分の効率的利用を図っている. 大根は 窒素を多く必要とする一方, 甘藷はほとんど必要と しない。このよらな養分要求の違いが一括施肥を可 能にしている ${ }^{2}$. さらに，3）両作物の連作障害の一 因である線虫は土壤表層に発生するので，甘藷移植 前に土㙋を耕耘しないことで線虫の土中拡散を防ぐ ことができる。畔をマルチで被覆するため土壌表層 は夏期に高温になり，表層の線虫は死滅する。これ により，土壌消毒を行らことなく連作障害を回避で きる，以上から，新技術は経営面，環境面双方の課 題解決に寄与する可能性を持つ（表 1 ).

\section{(3) 研究の目的}

環境面に打ける新技術の導入効果は既に実証され ている ${ }^{3}$. そのため, 本稿では経営面に打ける導入 効果を定量的に計測し, 技術の普及可能性を検討す ることを目的とする．分析対象は，新技術の現地実 証試験協力農家の A 農家である. A 農家は家族経営 （常雇なし）であり，甘藷，露地野菜，水稲の複合経 営である。また，経営規模が 10 ha を超える担い手
農家である．高齢農家の離農に伴う耕作放棄地の増 加が問題となっている南九州に拈いては, 農地の受 け手となる担い手経営の発展が特に重要な課題とな っている。な拝，2010 年農林業センサスによると， 南九州畑作地域に抢栋経営規模 4 ha 以上の担い手 の経営形態は, 家族経営（常雇なし）が最多である. また，畑作と水田作との複合経営が主要な営農類型 の一つとなっている.

本稿では，1）A農家への聞き取り調査から，当該 地域の家族経営の現状と課題を整理する. 次いで, 2) 農作業日誌のデータを用いて新技術の収益性等を 計測し, 慣行栽培と比較する (技術単独での評価). さらに3）線形計画モデルを作成し，新技術の導入 に伴ら農業所得, 作付け体系の変化等を計測する(経 営レベルでの評価)。4）分析結果から新技術の経営 面に打汀導入効果と, 普及に向けた課題を提示す る.

なお，これまでの畑作物を対象とした技術評価研 究は, 葉菜類の収穫機の導入効果を計測した高橋 (2001)，根菜類の洗浄機械の導入効果を計測した中 川他（1996）等，機械化技術の評価が中心である. また環境負荷低減を目的とした輪作についても，栽 培面積拡大に対応するため各作物の機械化を伴ら体 系が評価対象となっている（中島，2000）。一方で, 本稿で対象とするような機械化を伴わない省力化・ 環境対応技術についての評価研究は匡とんど見られ ない.また，南九州畑作地域を対象とした経営研究 は，近年，大規模法人経営の形成や食品企業の農業 参入に関するものが中心である。一方，担い手の大 部分を占める家族経営を対象とした経営研究は不足 している. 特に生産構造の分析等, 作物の生産段階 を対象とした研究は杉本（1986）以降十分に行われ ていない.

\section{2. 対象農家の経営概要亡課題 \\ (1) 対象農家の経営概要}

A 農家の経営概要を表 2 に示す。 A 農家は南九州 畑作の代表的地域である宮崎県都城市に所在する. 家族労働力は 3 名であり, 経営面積は畑 10.0 ha, 水 田 5.5 ha である. 主要作付计作物は, 焼酎原料用甘 藷と水稲である、甘著は酒造会社との契約生産であ り，経営主は価格の安定性を評価している。甘都は 
表 2. 対象農家の経営概要

\begin{tabular}{|c|c|}
\hline 労働力 & 3名（50 代夫婦，息子), 臨時雇用（人参収穫期に数日間） \\
\hline 経営面積 & 畑 10.0 ha 水田 5.5 ha \\
\hline 作付作物 & $\begin{array}{l}\text { 焼酎原料甘藷（コガネセンガン，ムラサキマサリ） } 10 \mathrm{ha}, \text { ジュース加工用人参 } 50 \mathrm{a} \text {, 新技術の試験区 } 15 \mathrm{a} \text {, } \\
\text { 主食用水稲（ヒノヒカリ，マイヒカリ） } 4 \mathrm{ha} \text {, イタリアンライグラス } 1 \mathrm{ha} \text {, その他（里芋等） }\end{array}$ \\
\hline 水稲作業受託 & 耕耘・田植え受託 2～3 ha，収穫受託 10 ha，乾燥受託 18 ha \\
\hline \begin{tabular}{c|} 
主な機械 \\
施設装備 1$)$
\end{tabular} & 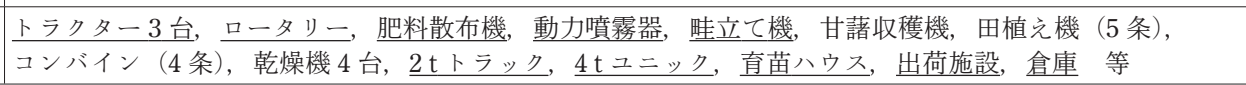 \\
\hline
\end{tabular}

1）下線を引いたものは複数作物に共通して使用するものである.

作業適期が長く, 移植は 4 月〜 6 月，収穫は 8 月〜 12 月まで可能である。 A 農家はこのような甘藷の特 性を利用し労働ピークを分散させ，作付け規模を拡 大している。ささらに，水稲作（6月移植，10月収 穫）を組み合わせることで労働をより分散させ，家 族労働力の有効利用を図っている. 一方で，有力な 冬作物が不在のため, 冬期は労働力を十分に活用で きていない.

保有する機械施設は数 ha 規模で効率的運用が可 能な小〜中型のものが中心であり，多くが畑作と水 田作に共通して利用できる，水稲作では専用機械を 一式保有するが，近隣農家の作業受託により稼働率 を高めている，このように，複合経営でありながら 機械施設を効率的に運用している.

\section{(2) 対象農家の課題}

経営状況について尋祆たところ,「夫婦の労働報酬 の一部を息子に分配することで，息子には他産業並 みの所得を確保している」という。大規模経営であ っても，地域の他産業従事者と同水準の所得を確保 できていないことが窥える ${ }^{4}$. しかし，ピーク時の 労働時間は一日 9〜10 時間となって抢り，家族 3 人 で経営できる限界規模に達している. 常雇の導入が 一つの有効な手段だが，労務管理のコスト増，周年 雇用の難しさ等からその意向はない。 また，畑作機 械の新規導入，大型化の意向もない. 理由は，1）近 年の企業参入等の影響から平場で区画が大きく, 自 宅から近い畑地は借地困難であり, 機械の効率的運 用が可能な規模まで経営面積を拡大できないこと, 2）規模拡大に伴い，機械化できない工程で大量の雇 用が必要になること，3）水稲作の機械設備を保有し ているため, 畑作機械の大型化は経営全体として非 効率になることである. 以上より, 対象農家の所得 向上に向けた課題は，(1)機械化以外の手段による家
族労働時間あたり所得の向上, (2)冬期の労働力の有 効活用である.

\section{3. 新技術の導入効果一技術単独での評価一 (1) 作業労働時間}

新技術の作業は 12 月より始まり，施肥，耕耘，畴 立ての後，大根，え几麦（畦間）を播種する。また 大根の保温のため不織布トンネルを畘上に設置する. 播種，トンネル設置は手作業のため時間を要する. その後翌年の 3 月にトンネルを撤去し， 3 月下旬か ら 4 月にかけて大根を手作業で収穫する. 収穫後は 畴をそのまま利用し，4 月下旬〜 5 月に甘藷を移植す る. この頃にえん麦が茂るため睢間の除草の必要は なく, 大根収穫後のマルチの穴から生える雑草の除 草のみでよい. その後 10 月末～11 月に甘諸を掘り 取り機で収穫し, 収穫後に大根作の準備に入る. 冬 期に作業がある点, 水稲作の繁忙期（6月と 10 月） に作業がない点が $\mathrm{A}$ 農家に導入する際の利点で ある。

新技術の $10 \mathrm{a}$ あたり作業労働時間は年 141 時間 （大根 103 時間，甘藷 38 時間）である ${ }^{5}$. 慣行栽培 と比較すると, 新技術の甘藷作では耕耘, 施肥, 畦 立て, 消毒, 畦間の除草作業が省略できるため, 慣 行の甘藷単作より作業労働時間が 5.9 時間/10 a 短 い. 大根作では，えん麦の播種作業が加わるが，収 穫後のマルチ撤去作業を省略でき, 慣行の春大根単 作と比較し作業労働時間が 0.7 時間 $/ 10 \mathrm{a}$ 短い.

\section{（2）物財費}

新技術の $10 \mathrm{a}$ あたり物財費は 18.8 万円, 慣行春大 根と慣行甘諸をそれぞれ単作で栽培した場合の物財 費の合計（各 $10 \mathrm{a}$ ，合計 $20 \mathrm{a}$ ）は 22.7 万円であり， 3.9 万円の削減が可能である ${ }^{6}$. 新技術ではえん麦播 種により種苗費が 4,500 円増加するが, 被覆資材費 
8,800 円, 動力費 630 円, 肥料費 16,200 円, 殺虫剂・ 除草剂費 15,100 円等の削減が可能である.

\section{(3) 粗収益}

試験区で栽培した春大根の単収は約 5,300 kg/10 a である．鹿児島市内のスーパーに直接出荷しており， 収穫量の約 8 割が青果用，成長しすぎて味が落ちた もの等 2 割が加工用となる。単価はそれぞれ 86 円/kg，23 円/kg（2013 年実績值）であり，10 a あた り粗収益は約 40 万円となる.な敃，新技術と慣行栽 培の単収, 単価に違いはない. 甘藷は慣行栽培のも のが単収 3,200 kg/10 a であり，新技術では移植前作 業の省略により移植時期が前進するため, 約 1 割多 い3,500 kg/10 a である. 単価はともに 55 円/kg (2013 年実績值) であり，10 a あたり粗収益は慣行 17.6 万 円，新技術 19.3 万円となる.

以上の結果より，家族労働 1 時間あたり農業所得 を試算すると，新技術が 2,380 円となり，甘藷単作 1,980 円，春大根単作 1,750 円を上回る.

\section{4. 新技術の導入効果一経営レベルでの評価一}

\section{（1）線形計画モデルの作成}

表 3 に A 農家の作業日誌及び経営記録より集計・
分析した新技術を含む主要作物の 10 a あたり作業労 働時間，利益係数を示す 7 、甘藷は収穫時期によっ て単収と単価が異なり，利益係数も異なる。これら の数值を使用し, 計 61 プロセスの線形計画モデルを 構築した. プロセスは畑作, 水田作, 水稲作業受託, 臨時雇用の 4 つの大区分に分類した. さらに，畑作 はコガネセンガン (8月〜12 月収穫)，ムラサキマ サリ（11月，12月収穫)，人参（単作，甘藷と二毛 作), 春大根単作，新技術 (二毛作), 水田作はと) ヒカリ，マイヒカリ，コガネセンガン（5プロセス）, ムラサキマサリ（2プロセス），イタリアン（単作, 水稲裏）とした. 作業受託は耕耘・田植え受託, 収 穫受託，乾燥受託，雇用は各月， 3 旬の計 36 プロセ スとした。な抏，水田への甘藷作付けは湿害による 収量低下を招くため, 水田作の甘藷の利益係数は畑 作より低く設定した. 水稲価格は平成 25 年産，水稲 助成は 7,500 円/10 a, 転作助成（イタリアン）は 35,000 円/10 a, 水稲作業受託料金は JA 都城の基準, 臨時雇用労賃は 745 円/h とした。また，制約条件と して，各月旬別の家族労働制約（降雨量 $10 \mathrm{~mm}$ 未満 の日数 $\times 9$ 時間 $\times 3$ 名)，畑作付制約（現状の経営面 積), 水田作付制約 (現状の経営面積)，転作制約（転

表 3. 新技術及び慣行栽培の各作物の 10 a あたり作業労働時間と利益係数

\begin{tabular}{|c|c|c|c|c|c|c|c|c|c|}
\hline & & \multicolumn{2}{|c|}{ 新技術（二毛作） } & \multicolumn{6}{|c|}{ 慣行栽培（単作） } \\
\hline & & \multirow{2}{*}{ 春大根 } & \multirow{2}{*}{ コガネセンガン } & \multicolumn{5}{|c|}{ コガネセンガン } & \multirow{2}{*}{ ヒノヒカリ } \\
\hline & & & & 8 月収穫 & 9 月収穫 & 10 月収穫 & 11 月収穫 & 12 月収穫 & \\
\hline \multicolumn{2}{|c|}{ 利益係数 1) (円) $^{-1}$} & 265,156 & 168,700 & 98,967 & 111,337 & 119,417 & 117,134 & 88,537 & 77,045 \\
\hline \multirow{13}{*}{$\begin{array}{c}\text { 労働時間 } \\
\text { (時間) }\end{array}$} & 1月 2) & & 0.24 & 0.24 & 0.24 & 0.24 & 0.24 & 0.80 & \\
\hline & 2 月 & & 0.60 & 0.60 & 0.60 & 0.60 & 0.52 & 0.52 & \\
\hline & 3 月 & 22.70 & 0.60 & 2.42 & 2.44 & 0.60 & 0.52 & 0.52 & \\
\hline & 4 月 & 39.80 & 5.79 & 12.75 & 3.88 & 3.42 & 0.87 & 0.22 & \\
\hline & 5 月 & & 4.37 & 2.79 & 9.51 & 11.81 & 5.08 & 4.26 & 2.00 \\
\hline & 6 月 & & 0.60 & & 0.63 & 0.56 & 8.80 & 11.73 & 4.13 \\
\hline & 7 月 & & 1.50 & 2.55 & 0.63 & 1.60 & 1.37 & 0.67 & 2.78 \\
\hline & 8 月 & & & 16.14 & & & & & 1.30 \\
\hline & 9 月 & & 1.00 & & 16.54 & 1.81 & 1.80 & & 2.02 \\
\hline & 10 月 & & 6.08 & & & 19.20 & & & 3.45 \\
\hline & 11 月 & & 18.23 & & & & 24.27 & & \\
\hline & 12 月 & 40.50 & & 0.54 & 0.54 & 0.54 & 0.54 & 18.00 & \\
\hline & 合計 & 103.00 & 38.30 & 38.03 & 35.01 & 40.38 & 44.01 & 36.72 & 15.68 \\
\hline
\end{tabular}

1）利益係数は，機械施設の償却費，一般管理費等の固定的生産費用を差し引く前の值である

2）実際の線形計画モデルでは上，中，下旬ごとに設定している. 
作率 30\%以上)，水稲作業受託制約（現状の受託面 積), イタリアン作付制約（収穫は畜産農家が行うた め現状の 4 ha を上限）を設定した．以上のモデルを 使用し, XLP8 最大となる作物別作付け面積を計測した。 (1)新技術 導入なし，(2)新技術導入，(3)新技術導入に加兄臨時 雇用が可能な場合, (4)新技術導入に加光水田の借地 が可能な場合（地代は 1 万円 $/ 10$ a）である。当該地 域では，今後高齢農家の離農に伴う水田供給面積の 増加が見込まれている。

\section{(2) 分析結果}

分析結果を表 4 亿示す. ケース(1)の作物別作付け 面積が $\mathrm{A}$ 農家の現状と泳淁一致していることから， モデルの精度は高いと言える。農業所得は 790 万 円，家族労働時間は年 5,995 時間となった。なお， 春大根単作はモデルに抒いても採用されない，ケー ス(2)では，新技術が 1.1 ha（延べ面積 2.2 ha）採択さ れる，甘藷単作が減少するが，これは作付けが単作 から二毛作に移行する他，新技術の大根の収穫期と 移植時期が重なる 8 月甘藷の作付け減少が要因とな っている. 結果, 甘藷の作付け延べ面積が減少し, 畑経営面積が約 1.5 ha 減少する。一方，水稲及び水 田の経営面積は変化しない。農業所得は 910 万円 (15\%増)，家族労働時間は年 6,132 時間（137 時間 増）となる。家族労働時間の増加は，冬期労働時間 の増加によるものである。また，家族労働 1 時間あ たり農業所得は 1,320 円から 1,480 円に増加する. ケース(3)では，大根収穫期の 4 月に 100 時間を上限 に臨時雇用が導入できる場合について分析した 9. ケース(2)に打いて, 労働の限界利益が 4 月労㗢に抒 いて最大値を示したためである. 新技術が 1.4 ha（延 べ面積 $2.8 \mathrm{ha}$ ) 採用され，農業所得は 1,010 万円 $(28 \%$ 増）となる。 ケース(4)では, 水田の借地により水稲 の作付けが拡大し, 烟経営面積が減少する。この場 合にも，新技術が 1.0 ha 採用される。

\section{5. おわりに}

本稿では, 南九州畑作地域の家族経営を対象に, ダイコン一サッマイモ畦連続使用栽培体系の導入効 果を計測した．分析の結果，新技術の導入により農 業所得が 120 万円（15\%）増加し，さらに春大根収 穫期の臨時雇用導入により 220 万円 $(28 \%)$ 増加す
表 4. 作物別作付面積と家族労働時間及び所得

\begin{tabular}{c|c|c|c|c}
\hline \hline & $\begin{array}{c}\text { (1)技術導 } \\
\text { 入なし }\end{array}$ & $\begin{array}{c}\text { (2)技術 } \\
\text { 導入 }\end{array}$ & $\begin{array}{c}\text { (3)雇用 } \\
\text { 導入可 }\end{array}$ & $\begin{array}{c}\text { (4)水田 } \\
\text { 借地可 }\end{array}$ \\
\hline 甘藷単作 & 94.5 & 68.0 & 65.0 & 54.0 \\
\hline 甘藷人参二毛作 & 5.5 & 5.5 & 5.5 & 5.5 \\
\hline 新技術 (二毛作) & 0.0 & 11.0 & 14.0 & 10.0 \\
\hline 水稲 & 39.0 & 39.0 & 39.0 & 73.0 \\
\hline イタリアン単作 & 11.0 & 16.0 & 16.0 & 40.0 \\
\hline 甘藷単作 & 5.0 & 0.0 & 0.0 & 4.5 \\
\hline 水田経営面積 & 55.0 & 55.0 & 55.0 & 117.5 \\
\hline 畑経営面積 & 100.0 & 84.5 & 84.5 & 69.5 \\
\hline 畑作付延べ面積 & 105.5 & 101.0 & 104.0 & 85.0 \\
\hline 家族労働時間 & 5,995 & 6,132 & 6,329 & 6,176 \\
(時間) & 790 & 910 & 1,010 & 1,020 \\
\hline 農業所得 (万円) & 790 \\
\hline
\end{tabular}

1）面積の単位は $10 \mathrm{a}$ であり，網掛的部分が畑，それ以外 が水田に扣ける作付面積である.

ることが明らかになった。家族一人あたり農業所得 は約 340 万円となり，地域の他産業に打沙常勤労 働者の平均年収を上回る。要因は，甘諸作の労働時 間と資材費の削減により家族労動時間あたり農業所 得が向上することに加え, 収益性が甘藷等に劣るこ とから単作では採用されなかった春大根が，二毛作 の後作として導入され農閉期の労働力の活用が図れ ることである. 南九州畑作地域の先進的家族経営は, 小〜中型機械体系の下で，家族労働による限界規模 にまで経営面積を拡大している，しかしながら，経 営形態や営農類型, 経営体が置かれている地理的・ 社会的条件によっては，さらなる機械化と規模拡大 による経営発展を描くことができない場合がある. 本稿では，二毛作を含む畑地の高度利用体系が，そ のような家族経営の所得向上飞寄与寸ることを示 した.

また, 新技術と水稲作の労働のピークは重ならず, 労衝の競合が小さい，そのため新技術の導入によっ て水稲の作付面積が大きく減少せず，このことが複 合経営の所得向上の一因となっている ${ }^{10}$. 今後, 担 い手経営として放棄水田の受け手となる場合に拈い ても，水稲作を拡大しつつ烟作部門の所得向上を図 ることができる.

最後に，新技術は新規の機械投資や技術習得を伴 わずに所得を向上できることから，現場への普及可 
能性は高いと言える。ただし，普及に向けては以下 の 3 点が課題となる. 1) 春大根の販路確保が課題で ある ${ }^{11}$. ただし, 收穫期の $3 \sim 4$ 月は大根の端境期に あたり，全国的に需要が大きい，A農家では現在試 験的に販売しているスーパーへの出荷量の拡大, 及 び県外の消費地への出荷を予定している．2）新技術 をより大面積で実施するためには，臨時雇用の確保 が課題となる. シルバー人材センタ一等と連携し, 今後増加する高齢離農者の雇用を図ることが有効で あると考光る. 3) 畑地の集約的利用は畑経営面積を 減少させる。地域社会への影響を考光た場合，担い 手農家からの農地流出を防ぐため, 例兄ば余剩とな った畑地を利用し，畜産農家との交換耕作による甘 藷一飼料作の地域的な輪作構築を図ることが有効で ある．飼料作との輪作は甘藷の生育を良好にし，ま た線虫害の抑制効果があるため, 経営面, 環境面に おいても導入意義は大きい.

\section{注}

1 宮崎県の東霧島, 鹿児島県の北大隅, 南薩を指す.

2 このよらな施肥設計に加え, 有機質肥料を多く投入すること から，大根と甘藷の二毛作を繰り返した場合でも地力低下等 の問題は生じない，詳しくは農研機構（2013）を参照.

3 農研機構 (2013) 等を参照.

4 平成 24 年宮崎県勤労統計調査によると，県内の製造業，建 設業，小売業等の他産業の常勤労働者の平均給与額は年間約 290 万円である.

5 新技術の作業労働時間は $\mathrm{A}$ 農家の作業日誌より, 単収, 単 価, 生産費は経営データより計測した，慣行甘藷についても 同様である。ただし，新技術の甘藷作と同じ 10 月末〜 11 月 收穫の慣行甘藷のみ抽出し平均値を使用した。 慣行春大根に ついては, 新技術と共通する作業は新技術の作業労働時間, その他の作業は平成 22 年宮崎県農業経営管理指針の数值を 使用した。 また，単収，単価は新技術の数值，物財費は新技 術の数值と平成 22 年宮崎県農業経営管理指針の数值を使用 した.

6 物財費のうち機械施設の償却費等は $\mathrm{A}$ 農家における費用を現
状の作物別作付け面積で按分し 10 a あたりに換算した值を用 いた.

7 作業日誌に打いて, 各種作業の面積あたり作業時間に男女差 が見られなかったため, 労働係数は男女別に設定していない.

${ }^{8}$ XLPについては農研機構（2015）を参照.

9 上限の 100 時間/月は, $\mathrm{A}$ 農家の甘藷作, 人参作に打ける雇用 実績に基づくものである.

10 比較のために, 新技術の導入がない状態で水田が借地可能と なるケースを分析した結果, 水稲作付面積が 7.5 ha, 農業所 得が 907 万円となる. 分析ケース(4)との比較から，水田が借 地可能な状況下に抲いても, 新技術の導入により水稻の作付 面積は大きく減少せず，農業所得が向上する.

11 大根の出荷作業については, 固場で葉を切り落とし, 泥を落 としてそのまま箱詰めするため, 大規模な出荷施設や大量の 雇用労働は必要ない，A 農家は，栽培面積が 1 ha 程度に増加 した場合でも個人出荷が可能であると回答している.

\section{引用文献}

金岡正樹（2010）「九州沖縄地域における地域農業の構造展望 と農業経営の展開方向一南九州畑作の企業的畑作経営を素 材として一」『中央農業総合研究センタ一経営研究』 60 , 53-62.

杉本文三（1986）「南九州畑作経営に打ける土地利用問題」『農 業経営研究』23(3), 18-27.

高橋伸幸（2001）「全自動移植機・半自動収穫機を導入したキ 中ベッ機械化一貫体系の経済性」『関東東海農業経営研究』 92, 87-91.

中川 暁・堀内久太郎・塩谷幸治（1996）「ダイコン作に扮け る新技術の経営評価」『農業経営通信』190, 10-13.

中島征夫（2000）『地域複合農業の展開論理一地域営農をみつ めて一』農林統計協会.

農研機構（2013）「ダイコンーサッマイモ畦連続使用栽培システ ム」 (http://www.naro.affrc.go.jp/publicity_report/publication/ files/une_renzokusiyou.pdf) [2015 年 3 月 15 日参照 $]$.

農研機構 (2015)「線形計画法プログラム XLP」（http:// fmrp.dc.affrc.go.jp/programs/mathprograming/xlp/）［2015 年 3 月 15 日参照].

持田秀之（1995）「南九州畑作付体系の現状と技術的展望」『九 州の雑草』25, 23-28. 